\title{
Short communication: Effects of dietary nitrogen concentration on messenger RNA expression and protein abundance of urea transporter-B and aquaporins in ruminal papillae from lactating Holstein cows
}

\author{
B. A. Røjen, ${ }^{* 1}$ S. B. Poulsen, † P. K. Theil, ${ }^{*}$ R. A. Fenton, $†$ and N. B. Kristensen* \\ *Department of Animal Health and Bioscience, Faculty of Agricultural Sciences, Aarhus University, DK-8830 Tjele, Denmark \\ †The Water and Salt Research Center, Department of Anatomy, Aarhus University, DK-8000 Aarhus, Denmark
}

\begin{abstract}
To test the hypothesis that dietary $\mathrm{N}$ concentrations affect gut epithelial urea transport by modifying the expression of urea transporter B (UT-B) and aquaporins (AQP), the mRNA expression and protein abundance of UT-B and AQP3, AQP7, AQP8, and AQP10 were investigated in ruminal papillae from 9 lactating dairy cows. Ruminal papillae were harvested from cows fed low N (12.9\% crude protein) and high N ( $17.1 \%$ crude protein) diets in a crossover design with 21-d periods. The mRNA expression was determined by real-time reverse transcription-PCR and protein abundance by immunoblotting. The mRNA expression of UT-B was not affected by dietary treatment, whereas mRNA expression of AQP3, 7, and 10 were greater in the high $\mathrm{N}$ compared with the low $\mathrm{N}$ fed cows. Using peptide-derived rabbit antibodies to cow AQP3, 7, and 8 , immunoblotting revealed bands of approximately 27,27 , and $24 \mathrm{kDa}$ in ruminal papillae, respectively. A peptide-derived chicken antibody to cow UT-B detected a band of approximately 30 to $32 \mathrm{kDa}$ in ruminal papillae. The abundance of UT-B and AQP3 and 7 were not affected by dietary treatment. In contrast, the abundance of AQP8 was greater in high $\mathrm{N}$ compared with low $\mathrm{N}$ diets. In conclusion, AQP3, 7, and 8 were found to be expressed in bovine rumen papillae. None of the investigated transcripts or proteins correlated to the increased rumen epithelial urea permeability observed with low dietary $\mathrm{N}$ concentration.
\end{abstract}

Key words: dairy cow, urea transporter B, aquaporin, nitrogen

\section{Short Communication}

Ruminants recycle endogenous urea to the forestomachs where it can be utilized for microbial protein syn-

Received December 7, 2010.

Accepted January 23, 2011.

${ }^{1}$ Corresponding author: Betina.AmdisenRojen@agrsci.dk thesis (Lapierre and Lobley, 2001). Dairy cows adapt to dietary $\mathrm{N}$ status by upregulating the extraction ratio of arterial blood urea across the portal-drained viscera and ruminal epithelia when fed rations with decreasing dietary $\mathrm{N}$ concentration (Røjen et al., 2008a; Calsamiglia et al., 2010). However, urea transport across gut epithelia in lactating cows is proportional to arterial blood urea concentrations and mass action regulated in the short-term (Kristensen et al., 2010). Facilitative urea transporters (UT) play an important role in the urinary concentrating mechanism (Fenton et al., 2004) and in the salvage of urea from renal excretion (Isozaki et al., 1994), and expression levels of UT offer a possible mechanism for explaining changes in urea permeability of the portal-drained viscera and ruminal epithelia under changing dietary $\mathrm{N}$ conditions. Expression of UT in the gastrointestinal tract of lambs (Marini et al., 2004; Ludden et al., 2009), heifers (Marini and Van Amburgh, 2003), and lactating cows (Røjen et al., 2008b) adds support for a physiological role of UT in gut epithelial urea transport. The genomic structure of one UT in bovine ruminal tissues, bovine UT-B, has been characterized (Stewart et al., 2005), but the physiological role of epithelial UT-B expression in urea salvaging remains equivocal in ruminants (Marini and Van Amburgh, 2003; Marini et al., 2004; Røjen et al., 2008b). The aquaporins (AQP), a family of water transporter proteins, might be involved in the urea salvage mechanism because several AQP are expressed in tissues of the gastrointestinal tract (Ma and Verkman, 1999), and AQP3, AQP7, AQP9, and AQP10 have been shown to be permeable to urea; the capability of AQP8 to transport urea is still debated (Echevarría and Ilundáin, 1998; Rojek et al., 2008; Litman et al., 2009). However, the expression and physiological role of AQP in regulating urea permeability of gut epithelia in lactating cows is unknown.

The objective of the present study was to investigate whether UT-B and AQP expression in bovine ruminal papillae correlated with the observed change in urea transport properties of gut epithelia of the cows when 
Table 1. Primers and probes ("-" indicates SYBR assay) used in real-time reverse-transcription PCR

\begin{tabular}{|c|c|c|c|c|c|}
\hline Gene $^{1}$ & Accession no. & $\begin{array}{l}\text { Amplicon } \\
\text { length (bp) }\end{array}$ & $\begin{array}{l}\text { Forward } \\
\text { primer }^{2}\end{array}$ & Probe & $\begin{array}{l}\text { Reverse } \\
\text { primer }^{2}\end{array}$ \\
\hline AQP3 & NM_001079794 & 103 & $5^{\prime}$-cgcgagccctggatca & - & 5'-cccagatcgcatcgtaatacaa \\
\hline AQP7 & NM_001076378 & 129 & $5^{\prime}$-tgcggccttgaccttcac & - & $5^{\prime}$-gcgttgtagaagaggccgtaga \\
\hline UT-B & NM_001008666 & 65 & 5 -tatgtccatgacgtgtccagtct & - & 5 -gcaggtcccatttgctcaac \\
\hline$\beta$-actin & AY141970 & 113 & $5^{\prime}$-acccagatcatgttcgagacctt & $5^{\prime}$-ctgtatgcctctggccgcacca & $5^{\prime}$-tcaccggagtccatcacgat \\
\hline GAPDH & AB098934 & 76 & 5'-gtcggagtgaacggatttgg & $5^{\prime}$-cgcctggtcaccagggctgct & $5^{\prime}$-caatgtccactttgccagagttaa \\
\hline
\end{tabular}

${ }^{1} \mathrm{AQP}=$ aquaporin; UT-B $=$ urea transporter $\mathrm{B}$.

${ }^{2}$ The underlined bases denote known splice-sites.

fed low or high $\mathrm{N}$ rations. It was hypothesized that mRNA expression and the protein abundance of UT-B and several AQP would increase in lactating dairy cows supplied with low $\mathrm{N}$ compared with high $\mathrm{N}$ diets. To investigate this we used real-time reverse transcription (RT)-PCR and immunoblotting techniques applied to biopsies of ruminal papillae.

The present experiment complied with the Danish Ministry of Justice, Law no. 382 (June 10, 1987), Act no. 726 (September 9, 1993), concerning experiments with animals and care of experimental animals.

A detailed description of the experiment was provided in a previous paper (Kristensen et al., 2010). Briefly, 9 Danish Holstein rumen-cannulated cows in second lactation were fed diets with low N (12.9\% CP) and high $\mathrm{N}(17.1 \% \mathrm{CP})$ in a crossover design. Cows were sampled on d 14 of each period. At 1100 to 1200 $\mathrm{h}$ on each sampling day, ruminal mucosa from the cranio-ventral sac (atrium) were biopsied by snapping off approximately 20 papillae. Five papillae were individually transferred to 2-mL tubes, snap frozen in liquid nitrogen, and stored at $-80^{\circ} \mathrm{C}$. Five papillae were submerged in RNA stabilization solution (RNAlater; Sigma-Aldrich Inc., St. Louis, MO) in 2-mL tubes, kept at $4^{\circ} \mathrm{C}$ overnight, and stored at $-80^{\circ} \mathrm{C}$.

To quantify the mRNA expression of UT-B and AQP3, 7, and 10 in ruminal papillae, real-time RT$\mathrm{PCR}$ was performed. Papillae were homogenized in 350 $\mu \mathrm{L}$ of RNeasy lysis buffer, the homogenate was diluted with $70 \%$ ethanol (1:1), and the RNA concentration was assessed using NanoDrop ND-1000 spectrophotometer (Thermo Fisher Scientific, Roskilde, Denmark). Purified RNA was reverse-transcribed with oligo-dT and random primers using the Superscript III RNase $\mathrm{H}$ reverse transcriptase kit (Invitrogen, Taastrup, Denmark) according to the manufacturer's protocol. Reverse-transcribed material $(1 \mu \mathrm{L})$ was amplified with TaqMan Universal PCR Master Mix (Applied Biosystems, Stockholm, Sweden) using primer pairs specific for each gene. Signal was detected quantitatively by using SYBR Green (UT-B and AQP3 and 7), or probes labeled with carboxyfluorescein (FAM) on the $5^{\prime}$ end (AQP10, GAPDH, and $\beta$-actin). The oligonucleotide sequences for the genes were designed using Primer Express software, version 2.0 (Applied Biosystems Inc.). The sequences of forward primer, probe (in case it was used), and reverse primer for the studied genes are described in Table 1 . Transcription of $\beta$-actin and GAPDH were tested as possible endogenous controls, and both housekeeping genes were considered suitable for the present study. The samples were analyzed using an ABI 7900HT detection system (Applied Biosystems). A selected sample was diluted serially and analyzed in triplicate to test the linearity and efficiency of the PCR amplifications. Furthermore, control wells with water and genomic cow DNA were used as negative controls. For RT-PCR, 40 cycles were needed at $95^{\circ} \mathrm{C}$ for $15 \mathrm{~s}$, and $60^{\circ} \mathrm{C}$ for $60 \mathrm{~s}$ to amplify the PCR products. All the target genes were analyzed in duplicate and the housekeeping genes in triplicate and the response was quantified as the number of PCR cycles required to reach a certain threshold [cycle threshold (Ct) values]. The relative mRNA expression was calculated essentially by using the formula: Relative expression $=2^{-\Delta \Delta \mathrm{Ct}}$, although PCR efficiencies below 100\% were taken into account, as described by Theil et al. (2006).

For this study, new antibodies to AQP3, 7, and 8 were prepared. The antibodies used had the following AA sequences: AQP3 RA8260: MGRQKELMNRC; AQP7 2275/1051: CAINPSRDLPPRF; and AQP8 2277/1310: CLFIGDEKTRLILKSR. The antibody to UT-B (a gift from Gavin Stewart, University College, Dublin, Ireland) was characterized previously with the AA sequence BUTB-PAN: EENRIFYLQSRKRTVQGPL; Simmons et al., 2009). The antibodies were polyclonal and raised against a synthetic peptide in rabbit (AQP3, 7, and 8) or in chicken (BUTB-PAN). Ruminal abundance of AQP10 was not investigated in the present study because no suitable antibody was available at time of the experiment.

For immunoblotting, ruminal papillae were homogenized in dissecting buffer ( $0.3 \mathrm{M}$ sucrose, $25 \mathrm{~m} M$ imida- 
Table 2. Expression of mRNA quantified by real-time PCR in ruminal papillae of lactating dairy cows fed a low $\mathrm{N}$ or high $\mathrm{N}$ diet

\begin{tabular}{lccc}
\hline & \multicolumn{2}{c}{ Treatment $^{2}$} & \\
\cline { 2 - 3 } Gene $^{1}$ & Low N & High N & $P$-value \\
\hline AQP3 & 1.00 & 1.33 & 0.03 \\
& {$[0.83 ; 1.21]$} & {$[1.10 ; 1.61]$} & \\
AQP7 & 1.00 & 1.59 & 0.02 \\
& {$[0.80 ; 1.25]$} & {$[1.27 ; 1.99]$} & \\
AQP10 & 1.00 & 1.55 & 0.02 \\
& {$[0.77 ; 1.29]$} & {$[1.22 ; 1.96]$} & \\
UT-B & 1.00 & 1.17 & 0.32 \\
& {$[0.80 ; 1.24]$} & {$[0.94 ; 1.45]$} & \\
\hline
\end{tabular}

${ }^{1} \mathrm{AQP}=$ aquaporin; UT-B $=$ urea transporter $\mathrm{B}$.

${ }^{2}$ Treatments were a TMR with a low $\mathrm{CP}$ content (low N; $12.9 \% \mathrm{CP}$ ) and a high $\mathrm{CP}$ content (high N; $17.1 \% \mathrm{CP}$ ). Results are relative to the low $\mathrm{N}$ treatment. Lower and upper $95 \%$ confidence limits are given in brackets.

${ }^{3} P$-value for treatment effect.

zole, and $1 \mathrm{~m} M$ EDTA, $\mathrm{pH} 7.2$ ) containing the protease inhibitors leupeptin $(8.5 \mathrm{M})$ and phenylmethylsulfonyl fluoride $(1 \mathrm{mM})$, and the phosphatase inhibitors okadaic acid $(100 \mathrm{n} M)$, sodium orthovanadate $(1 \mathrm{~m} M)$, and sodium fluoride $(25 \mathrm{mM})$. The homogenates were centrifuged at $1,000 \times g$ for $15 \mathrm{~min}$ at $4^{\circ} \mathrm{C}$ to remove nuclei, mitochondria, and any remaining large cellular fragments. Then, supernatants were combined with Laemmli sample buffer. One gel (Bio-Rad Laboratories, Hercules, CA) was Coomassie-stained to ensure that protein loadings in the lanes were consistent, whereas the other gels were subjected to immunoblotting. The gels were transferred by electroelution to Hybond-P nitrocellulose membranes (GE Healthcare, Little Chalfont, UK), which were blocked with $5 \%$ milk in PBS-Tween (PBS-T; $80 \mathrm{~m} M \mathrm{Na}_{2} \mathrm{HPO}_{4}, 20 \mathrm{~m} M \mathrm{NaH}_{2} \mathrm{PO}_{4}, 100 \mathrm{~m} M$ $\mathrm{NaCl}, 0.1 \%$ Tween 20, pH 7.5) for $1 \mathrm{~h}$ and incubated overnight with the primary antibodies AQP3 RA8260 (1:25), AQP7 2275/1051 (1:25), AQP8 2277/1310 $(1: 25)$, and BUTB-PAN $(1: 3,000)$ diluted in PBS-T supplemented with $0.1 \%$ BSA and $0.3 \%$ Triton X-100. The membranes were subsequently incubated for $1 \mathrm{~h}$ with anti-rabbit (Dako, Glostrup, Denmark; 1:3,000) or anti-chicken (Abcam, Cambridge, UK; 1:5,000) horseradish peroxidase-conjugated goat IgG secondary antibodies diluted in PBS-T containing 5\% milk. Labeling was visualized using an enhanced chemiluminescence system (GE Healthcare). Films were scanned with an Epson Perfection V700 Photo scanner (Seiko Epson Corp., Nagano, Japan), and labeling densities were quantified using the computer software Quantity One 4.6.9 (Bio-Rad Laboratories). Rat kidney and liver as well as cow kidney and liver were used as positive controls in immunoblots.

The mixed procedure in SAS software [version 9.1 (TS1M3), SAS Institute Inc., Cary, NC] was used for statistical analysis. The mRNA expression data (1 observation per cow $\times$ dietary treatment) were subjected to ANOVA according to the crossover design. Treatment sequence, period, and dietary treatment were considered fixed effects and cow within sequence as a random effect. For immunoblots, statistical comparisons were made by use of paired Student's t-test. Significance was declared at $P \leq 0.05$.

The mRNA expression of UT-B in ruminal papillae was not affected $(P=0.32$; Table 2$)$ by treatment. The mRNA expression of AQP3, 7, and 10 increased $(P=$ 0.02 to $P=0.03$ ) in high $\mathrm{N}$ compared with low $\mathrm{N}$ diets. Primers were also designed for AQP8 and 9 but the mRNA was not expressed sufficiently to quantify it.

The anti-UT-B BUTB-PAN labeled a strong band of approximately 30 to $32 \mathrm{kDa}$ in ruminal papillae of all cows (Figure 1). The antibody AQP3 RA8260 detected multiple protein bands; a strong band of approximately $27 \mathrm{kDa}$ was found in both cow and rat kidney. This band was also detected in the ruminal papillae. The AQP7 antibody detected a band of approximately $27 \mathrm{kDa}$ in rat kidney, and a similar band was detected in ruminal papillae of all cows. The AQP8 antibody detected a band of approximately $24 \mathrm{kDa}$ in ruminal papillae, rat kidney and liver, and cow kidney and liver.

The protein abundance of UT-B, AQP3, and AQP7 did not differ $(P=0.47$ to $P=0.92)$ between low $\mathrm{N}$ and high $\mathrm{N}$ treatments. The protein abundance of AQP8 was greater in high $\mathrm{N}$ compared with low $\mathrm{N}$ diets $(P=0.04$; Figure 1$)$.

Simmons et al. (2009) showed that UT-B expression was regulated by dietary energy intake, and data from transition dairy cows (Røjen et al., 2008b) indicated an association between reproductive status, adaptation to increased energy intake, or both, and UT-B mRNA expression. However, studies in lambs with decreasing dietary $\mathrm{N}$ intake were not able to demonstrate a correlation between UT-B expression and gut clearance of blood urea (Marini et al., 2004; Ludden et al., 2009). In contrast, Marini and Van Amburgh (2003) showed that UT-B was expressed more in dairy heifers fed a high $\mathrm{N}$ diet compared with those fed a low $\mathrm{N}$ diet. In the present study, BUTB-PAN labeled a strong band of approximately 30 to $32 \mathrm{kDa}$, which corresponds to the 30 - to $32-\mathrm{kDa}$ nonglycosylated bUT-B1 previously observed in bovine blood, kidney, and rumen protein samples (Simmons et al., 2009; Tickle et al., 2009). However, in the present study, protein abundance in ruminal epithelium did not differ between low and high $\mathrm{N}$ concentrations, in agreement with no effect of treatment on UT-B mRNA expression. In conclusion, the available data do not indicate a causal link of UT-B mRNA expression and UT-B abundance with gut epithelial urea transport. 
UT-B
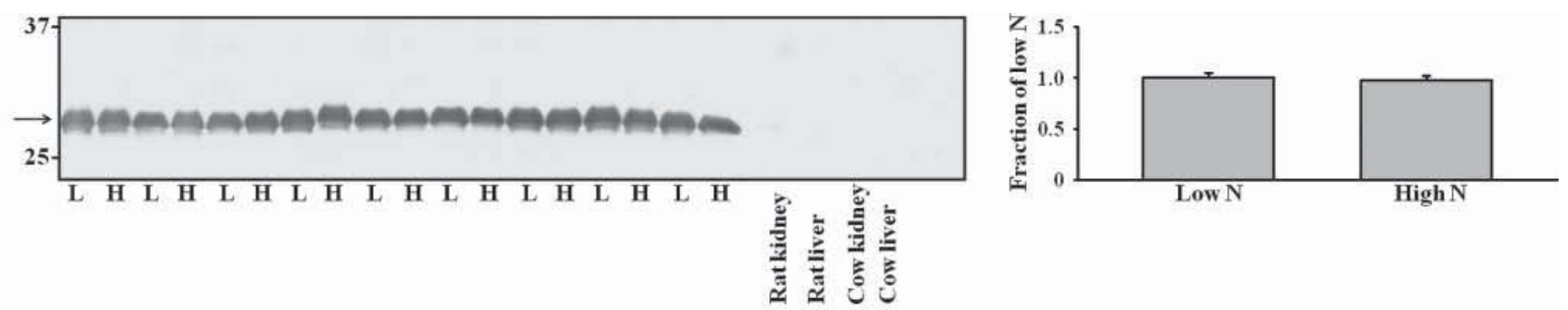

AQP3
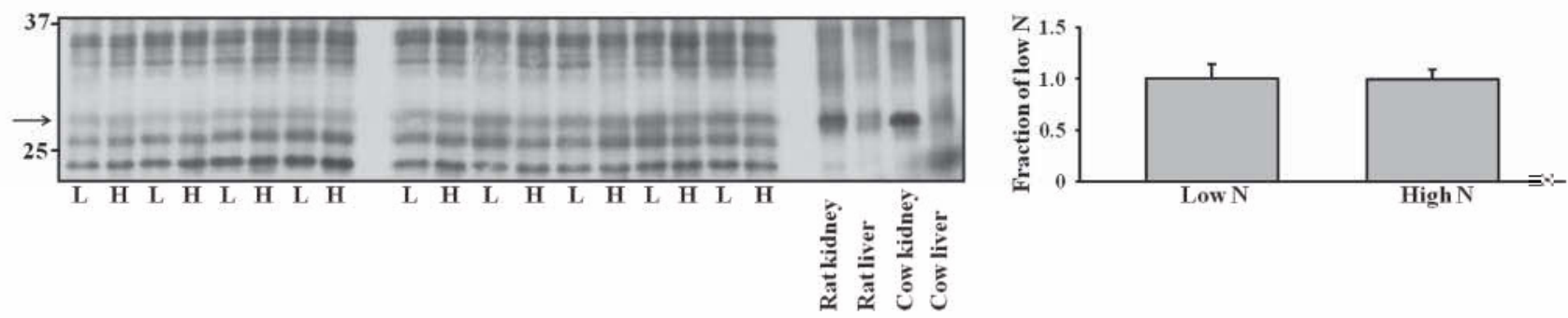

AQP7
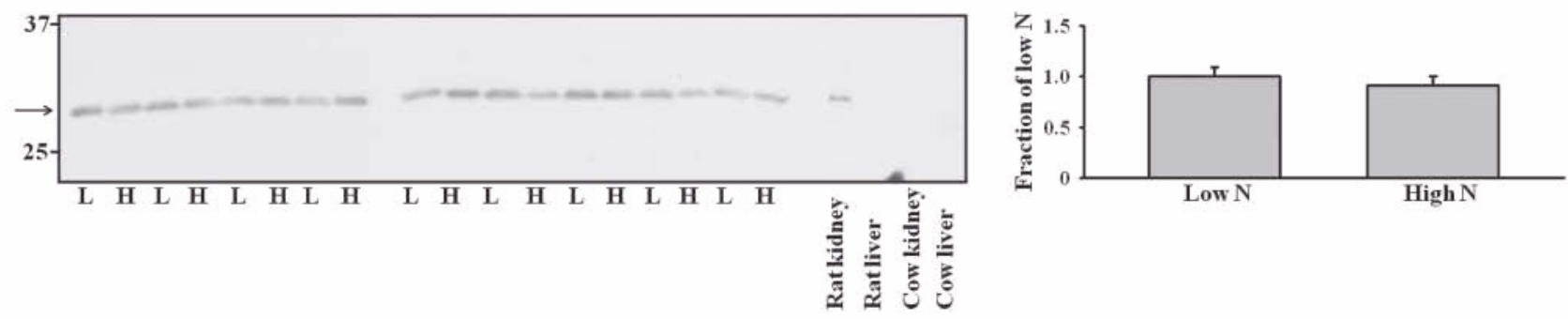

AQP8
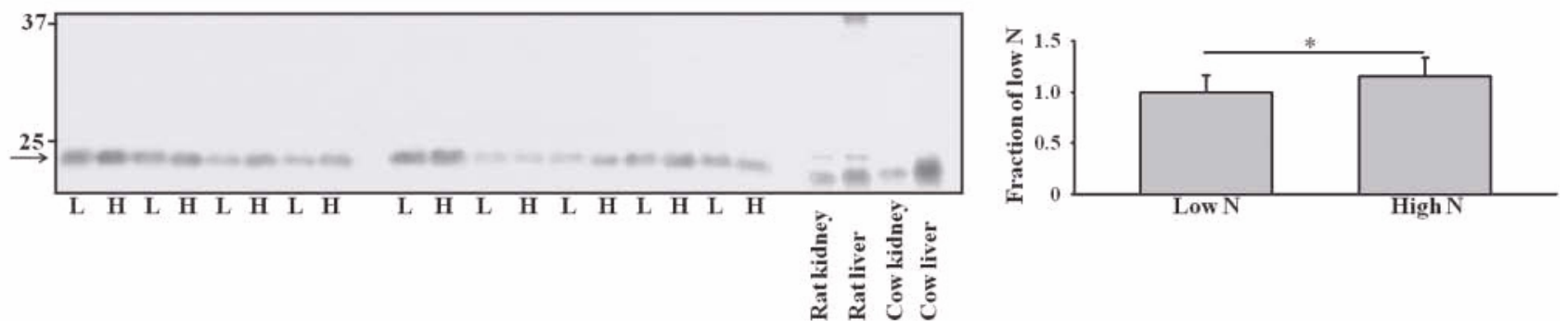

Figure 1. Immunoblots (left) and corresponding densitometric analyses (right) of protein abundance of urea transporter B (UT-B) and aquaporins (AQP) 3, 7, and 8 in ruminal papillae from lactating dairy cows fed a low $\mathrm{N}$ diet $(\mathrm{L} ; \mathrm{n}=9)$ or a high $\mathrm{N}$ diet $(\mathrm{H} ; \mathrm{n}=9)$. Samples of rat kidney, rat liver, cow kidney, and cow liver are presented as controls. An arrow indicates the band corresponding to the respective protein. Relative expression of UT-B (1.00 vs. $0.98 \pm 0.04)$, AQP3 (1.00 vs. $0.99 \pm 0.10)$, and AQP7 (1.00 vs. $0.91 \pm 0.09)$ were not affected $(P>0.10)$ by treatment. Relative expression of AQP8 (1.00 vs. $1.16 \pm 0.18)$ was greater in high $\mathrm{N}$ compared with low $\mathrm{N}$ diets. An asterisk $(*)$ indicates a statistically significant difference $(P<0.05)$. Values are given as mean $\pm \mathrm{SE}$.

Aquaporins 3, 7, 8, 9, and 10 are expressed in the colon and small intestine of rodents and humans (Ma and Verkman, 1999; Rojek et al., 2008) but the expression and physiological function of $\mathrm{AQP}$ are less investigated in ruminants. In the present study AQP3 RA8260 detected strong protein bands of approximately $27 \mathrm{kDa}$ in ruminal papillae, cow kidney, and rat kidney, which may correspond to the approximately $26-$ to $27-\mathrm{kDa}$ nonglycosylated AQP3 band expressed in rat kidney (Ecelbarger et al., 1995; Terris et al., 1996; Matsuzaki et al., 2001). The approximately 27-kDa AQP7 protein detected in rat kidney and in ruminal papillae of all cows presumably reflects a similar protein observed as a
28-kDa band in mouse kidney (Nejsum et al., 2000) and a 26-kDa band in rat kidney (Ishibashi et al., 1997). In the present study, AQP8 was detected as a $24-\mathrm{kDa}$ band in rat kidney and liver and cow kidney and liver as well as in ruminal papillae of all cows. Thus, the detected protein was smaller than the $28-\mathrm{kDa}$ band proposed to represent nonglycosylated AQP8 in mice (Yang et al., 2006) and rat liver (Koyama et al., 1997). Posttranslational processing or antibody cross-reactivity might explain the difference in molecular weight.

In the present study, AQP8, which may or may not be involved in urea transport (Rojek et al., 2008; Litman et al., 2009), was the only AQP found to be expressed 
differently between treatments. The observed decrease in abundance of AQP8 with the low $\mathrm{N}$ diet indicates that regardless of the function of AQP8 the abundance in ruminal papillae was not associated with the observed dietary effects on urea transport (Kristensen et al., 2010). In addition, the observed higher mRNA expression of AQP3, 7, and 10 with high $\mathrm{N}$ compared with low $\mathrm{N}$ diets suggests that the regulation of these AQP is affected by something other than dietary $\mathrm{N}$ concentration (e.g., water balance); therefore, the present study does not point to a role of AQP in regulating gut epithelial urea transport.

The present study demonstrates that several AQP are expressed in bovine ruminal papillae and that mRNA expression and protein abundance are affected by dietary $\mathrm{N}$ concentration. Messenger RNA expression of AQP3, AQP7, and AQP10 and abundance of AQP8 increased with increasing $\mathrm{N}$ intake. Thus, our findings do not point to these proteins as the cause of increased rumen epithelial urea permeability in dairy cows fed a low $\mathrm{N}$ diet. We were not able to relate UT-B protein abundance and UT-B mRNA expression to changes in dietary $\mathrm{N}$ concentration.

\section{ACKNOWLEDGMENTS}

B. A. Røjen held a PhD scholarship co-financed by Faculty of Life Sciences, University of Copenhagen, Frederiksberg C, Denmark (Department of Basic Animal and Veterinary Sciences) and Faculty of Agricultural Sciences, Aarhus University, Tjele, Denmark. Funding for the study was provided by the Commission of the European Communities (Brussels, Belgium; FP7, KBBE-2007-1), the Directorate for Food, Fisheries and Agri Business (Copenhagen, Denmark; \#3304-VMP05-005), and the Danish Ministry of Food, Agriculture and Fisheries, Copenhagen, Denmark.

\section{REFERENCES}

Calsamiglia, S., A. Ferret, C. K. Reynolds, N. B. Kristensen, and A. M. Van Vuuren. 2010. Strategies for optimizing nitrogen use by ruminants. Animal 4:1184-1196.

Ecelbarger, C. A., J. Terris, G. Frindt, M. Echevarria, D. Marples, S. Nielsen, and M. A. Knepper. 1995. Aquaporin-3 water channel localization and regulation in rat kidney. Am. J. Physiol. 269:F663-F672.

Echevarría, M., and A. A. Ilundáin. 1998. Aquaporines. J. Physiol. Biochem. 54:107-118.

Fenton, R. A., C. L. Chou, G. S. Stewart, C. P. Smith, and M. A. Knepper. 2004. Urinary concentrating defect in mice with selective deletion of phloretin-sensitive urea transporters in the renal collecting duct. Proc. Natl. Acad. Sci. USA 101:7469-7474.

Ishibashi, K., M. Kuwahara, Y. Gu, Y. Kageyama, A. Tohsaka, F. Suzuki, F. Marumo, and S. Sasaki. 1997. Cloning and functional expression of a new water channel abundantly expressed in the testis permeable to water, glycerol, and urea. J. Biol. Chem. 272:20782-20786.

Isozaki, T., A. G. Gillin, C. E. Swanson, and J. M. Sands. 1994. Protein restriction sequentially induces new urea transport processes in rat initial IMCD. Am. J. Physiol. 266:F756-F761.

Koyama, Y., T. Yamamoto, D. Kondo, H. Funaki, E. Yaoita, K. Kawasaki, N. Sato, K. Hatakeyama, and I. Kihara. 1997. Molecular cloning of a new aquaporin from rat pancreas and liver. J. Biol. Chem. 272:30329-30333.

Kristensen, N. B., A. C. Storm, and M. Larsen. 2010. Effect of dietary nitrogen content and intravenous urea infusion on ruminal and portal-drained visceral extraction of arterial urea in lactating Holstein cows. J. Dairy Sci. 93:2670-2683.

Lapierre, H., and G. E. Lobley. 2001. Nitrogen recycling in the ruminant: A review. J. Dairy Sci. 84(E. Suppl.):E223-E236.

Litman, T., R. Søgaard, and T. Zeuthen. 2009. Ammonia and urea permeability of mammalian aquaporins. Handb. Exp. Pharmacol. 190:327-358.

Ludden, P. A., R. M. Stohrer, K. J. Austin, R. L. Atkinson, E. L. Belden, and H. J. Harlow. 2009. Effect of protein supplementation on expression and distribution of urea transporter-B in lambs fed low-quality forage. J. Anim. Sci. 87:1354-1365.

Ma, T., and A. S. Verkman. 1999. Aquaporin water channels in gastrointestinal physiology. J. Physiol. 517:317-326.

Marini, J. C., J. D. Klein, J. M. Sands, and M. E. Van Amburgh. 2004. Effect of nitrogen intake on nitrogen recycling and urea transporter abundance in lambs. J. Anim. Sci. 82:1157-1164.

Marini, J. C., and M. E. Van Amburgh. 2003. Nitrogen metabolism and recycling in Holstein heifers. J. Anim. Sci. 81:545-552.

Matsuzaki, T., T. Suzuki, and K. Takata. 2001. Hypertonicity-induced expression of aquaporin 3 in MDCK cells. Am. J. Physiol. Cell Physiol. 281:C55-C63.

Nejsum, L. N., M. L. Elkjaer, H. Hager, J. Frokiaer, T. H. Kwon, and S. Nielsen. 2000. Localization of aquaporin-7 in rat and mouse kidney using RT-PCR, immunoblotting, and immunocytochemistry. Biochem. Biophys. Res. Commun. 277:164-170.

Rojek, A., J. Praetorius, J. Frøkiaer, S. Nielsen, and R. A. Fenton. 2008. A current view of the mammalian aquaglyceroporins. Annu. Rev. Physiol. 70:301-327.

Røjen, B. A., P. Lund, and N. B. Kristensen. 2008a. Urea and shortchain fatty acids metabolism in Holstein cows fed a low-nitrogen grass-based diet. Animal 2:500-513.

Røjen, B. A., P. K. Theil, M. Larsen, and N. B. Kristensen. 2008b. Correlation between UT-B mRNA abundance in ruminal epithelium and net portal flux in transition dairy cows. J. Anim. Sci. 86(E Suppl. 2):88. (Abstr.)

Simmons, N. L., A. S. Chaudhry, C. Graham, E. S. Scriven, A. Thistlethwaite, C. P. Smith, and G. S. Stewart. 2009. Dietary regulation of ruminal bovine UT-B urea transporter expression and localization. J. Anim. Sci. 87:3288-3299.

Stewart, G. S., C. Graham, S. Cattell, T. P. L. Smith, N. L. Simmons, and C. P. Smith. 2005. UT-B is expressed in bovine rumen: Potential role in ruminal urea transport. Am. J. Physiol. Regul. Integr. Comp. Physiol. 289:R605-R612.

Terris, J., C. A. Ecelbarger, S. Nielsen, and M. A. Knepper. 1996. Long-term regulation of four renal aquaporins in rats. Am. J. Physiol. 271:F414-F422.

Theil, P. K., I. L. Sørensen, M. Therkildsen, and N. Oksbjerg. 2006. Changes in proteolytic enzyme mRNAs relevant for meat quality during myogenesis of primary porcine satellite cells. Meat Sci. 73:335-343.

Tickle, P., A. Thistlethwaite, C. P. Smith, and G. S. Stewart. 2009 Novel bUT-B2 urea transporter isoform is constitutively activated. Am. J. Physiol. Regul. Integr. Comp. Physiol. 297:R323-R329.

Yang, B. X., D. Zhao, and A. S. Verkman. 2006. Evidence against functionally significant aquaporin expression in mitochondria. J. Biol. Chem. 281:16202-16206. 